\title{
Gambaran makroskopik dan mikroskopik limpa pada hewan coba postmortem
}

\author{
${ }^{1}$ Lidya R. Goni \\ ${ }^{2}$ Djon Wongkar \\ ${ }^{2}$ Sunny Wangko
}

\author{
${ }^{1}$ Kandidat Skripsi Fakultas Kedokteran Universitas Sam Ratulangi Manado \\ ${ }^{2}$ Bagian Anatomi-Histologi Fakultas Kedokteran Universitas Sam Ratulangi Manado \\ Email: reginagoni30@gmail.com
}

\begin{abstract}
Morphologic changes of dead cells of an organ may be used as one of the alternatives to determine the time of death. Studies about macroscopic and microscopic postmortem changes in organs related to estimation of time of death are still limited. This study was aimed to obtain the macroscopic and microscopic changes of spleen based on the variation of time intervals up to 48 hours postmortem. This was a descriptive observational study that used two domestic pigs as animal model. The results showed that the macroscopic changes in the spleen occurred at 5 hours postmortem, characterized by changes in color and length. The spleen looked darker and became shorter $(15 \mathrm{~cm}$ to $14.5 \mathrm{~cm})$. At 30 hours postmortem, whitish spots appeared on the surface of the spleen. The earliest microscopic changes occured at 5 hours postmortem, characterized by congestion of Malpighian corpuscles. At 24 hours postmortem, a lot of cells in the Malpighian corpuscles showed pyknotic nuclei, and at 48 hours postmortem, most of the cells in the Malpighian corpuscles had undergone karyorrhexis and karyolisis. Conclusion: The earliest macroscopic changes occured at 5 hours postmortem meanwhile the earliest microscopic changes occured at 5 hours postmortem as congestion of Mapighian corpuscles. The lymphocytes inside the corpuscles showed pyknotic nuclei at 24 hours postmortem and became karyorrhexis as well as karyolysis at 48 hours postmortem.
\end{abstract}

Keywords: macroscopic and microscopic description, spleen, postmortem

\begin{abstract}
Abstrak: Perubahan morfologi sel mati dari suatu organ dapat digunakan sebagai salah satu alternatif untuk menentukan lama waktu kematian. Penelitian mengenai perubahan makroskopik dan mikroskopik postmortem dari organ-organ sebagai alternatif perkiraan waktu kematian belum banyak dilakukan. Penelitian ini bertujuan untuk mendapatkan gambaran makroskopik dan mikroskopik limpa postmortem berdasarkan variasi waktu sampai 48 jam. Jenis penelitian ialah deskriptif observasional menggunakan dua ekor babi domestik sebagai hewan coba. Hasil penelitian menunjukkan perubahan makroskopik limpa pada hewan coba mulai tampak pada 5 jam postmortem ditandai dengan perubahan warna dan panjang limpa. Limpa tampak lebih gelap dan menjadi lebih pendek $(15 \mathrm{~cm}$ menjadi $14,5 \mathrm{~cm}$ ). Pada 42 jam postmortem muncul bercak-bercak pucat pada permukaan limpa. Perubahan mikroskopik limpa mulai tampak pada 5 jam postmortem yang ditandai dengan kongesti korpus Malpighi. Pada 24 jam postmortem sebagian besar limfosit dalam korpus memperlihatkan inti piknotik yang menjadi karioreksis dan kariolisis pada 48 jam postmortem.
\end{abstract}

Kata kunci: gambaran makroskopik dan mikroskopik, limpa, postmortem 
Menurut World Health Organization (WHO) kematian merupakan hilangnya tanda kehidupan secara permanen yang terjadi setiap saat setelah kelahiran hidup. ${ }^{1}$ Kematian merupakan fase akhir dalam kehidupan makluk hidup. Dalam kasus kematian yang tidak wajar salah satu alternatif yang dapat digunakan untuk membantu proses penyidikan yaitu dengan perkiraan waktu kematian yang ditentukan berdasarkan perubahan-perubahan yang dapat dilihat (eksternal) maupun yang harus diamati (internal). ${ }^{1}$

Kematian dibagi menjadi dua fase yaitu kematian somatik dan kematian biologik. Pada kematian somatik proses aerobik dalam sel akan terhenti, tetapi proses anerobik masih dapat berlangsung. Tandatanda kematian yang dapat diperiksa dalam stadium mati somatik ialah hilangnya pergerakan dan sensibilitas, berhentinya pernapasan serta berhentinya denyut jantung dan peredaran darah. Pada kematian biologik terjadi kematian organ atau jaringan tubuh yang timbul beberapa saat setelah kematian somatik. Daya tahan dari masing-masing organ atau jaringan berbedabeda, sehingga terjadinya kematian pada tiap organ atau jaringan tidak bersamaan. Setelah terjadi kematian maka akan terjadi perubahan pada organ tubuh. Perubahan tersebut dapat terjadi dini pada saat meninggal, beberapa saat setelah meninggal, sampai beberapa hari setelah meninggal. ${ }^{2}$

Pada penelitian-penelitian sebelumnya terhadap perubahan struktur mikroskopik berbagai organ dengan menggunakan hewan coba babi domestik didapatkan saat terjadi perubahan yang paling awal dan saat struktur organ tidak dapat diidentifikasi yang berbeda-beda untuk organ yang berbeda. ${ }^{3-5}$

Perubahan morfologi sel yang telah mati dapat digunakan sebagai salah satu alternatif untuk menentukan lama waktu kematian. Sampel yang ideal ialah sampel yang langsung didapat dari organ tubuh manusia. Dalam penelitian ini digunakan babi domestik sebagai hewan coba karena babi memiliki karakteristik anatomi dan fisiologi yang menyerupai manusia. ${ }^{6}$

\section{METODE PENELITIAN}

Jenis penelitian ini ialah deskriptifobservasional yang dilakukan di Bagian Anatomi-Histologi Fakultas Kedokteran Universitas Sam Ratulangi Manado dan Pusat Diagnostik Patologi Anatomi Manado pada bulan November 2016. Hewan coba yang digunakan ialah satu ekor babi dengan berat $\pm 20 \mathrm{~kg}$ yang secara fisik aktif, sehat, dan tidak ada luka.

\section{Prosedur Penelitian}

Hewan coba dimatikan dengan cara menusuk bagian jantung babi. Setelah berhenti bernapas, catat waktu kematian, suhu dan kelembaban ruangan, serta suhu badan hewan coba. Dilakukan pengamatan makroskopik dan dilanjutkan dengan pengamatan mikroskopik pada interval waktu 0 jam, 1 jam, 2 jam, 3 jam, 4 jam, 5 jam, 6 jam, 9 jam, 12 jam, 15 jam, 18 jam, 21 jam, 24 jam, 30 jam, 36 jam, 42 jam, dan 48 jam. Sampel untuk pemeriksaan mikroskopik yaitu jaringan limpa diambil dengan ukuran $0,5 \times 0,5 \times 0,5 \mathrm{~cm}$. Semua sampel difiksasi dengan formalin $10 \%$ dan dilanjutkan untuk pembuatan sediaan histologik dengan pewarnaan hematoksillin eosin. Sediaan histologik diidentifikasi dengan mikroskopik cahaya Olympus CX21FS1 dan Optilab viewer.

\section{HASIL PENELITIAN \\ Gambaran makroskopik limpa}

Perubahan warna, konsistensi dan panjang organ limpa diamati dengan berbagai variasi interval waktu.

Pada 0 jam postmortem, tampak gambaran limpa berwarna merah tua dengan konsistensi kenyal dan panjang organ $15 \mathrm{~cm}$ (Gambar 1). Pada 2 jam postmortem, permukaan limpa mulai kering tetapi konsistensi tetap kenyal dengan panjang tetap. Pada 5 jam postmortem, warna limpa berubah coklat kehitaman dengan konsistensi tetap sama tetapi panjangnya berubah menjadi $14,5 \mathrm{~cm}$. Pada 18 jam postmortem, warna limpa menjadi hitam pekat dengan konsistensi kenyal, permukaan kering, dan tepi mulai mengerut (Gambar 2). Pada 30 jam postmortem, 
mulai tampak banyak bercak-bercak pucat pada bagian tengah organ limpa yang semakin banyak hingga 48 jam postmortem (Gambar 3).

\section{Gambaran mikroskopik limpa}

Pada perubahan mikroskopik limpa dinilai trabekula, korpus Malpighi, dan arteri sentralis. Pada hewan coba ini terdapat arteri Hulsen yang tidak ditemukan pada manusia sehingga tidak dilakukan pengamatan khusus terhadap arteri tersebut.

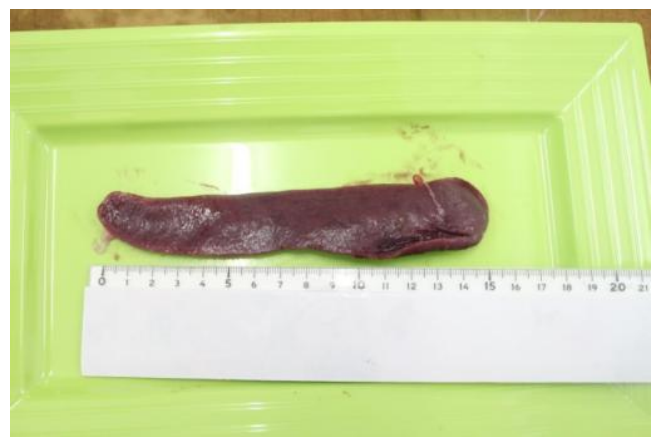

Gambar 1. Limpa hewan coba 0 jam postmortem

Pada 0 jam postmortem, struktur korpus Malpighi beserta arteri sentralis, trabekula, dan arteri Hulsen dapat diidentifikasi. Pada 5 jam postmortem, korpus Malpighi tampak kongesti dengan batas tidak jelas. Pada 24 jam postmortem, tampak kongesti korpus Malpighi, sebagian besar sel dalam korpus Malpighi dengan

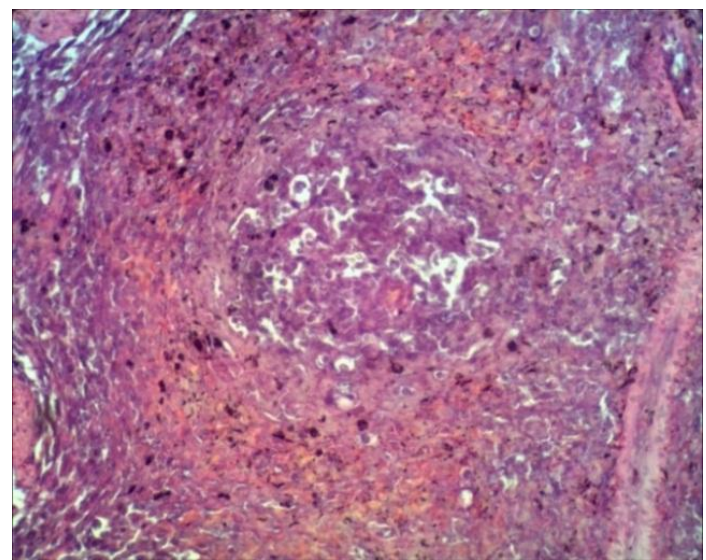

Gambar 4. Limpa hewan coba 0 jam postmortem. Struktur korpus Malpighi dan arteri sentralis dapat diidentifikasi. Trabekula dan arteri Hulsen dapat diidentifikasi. (400x)

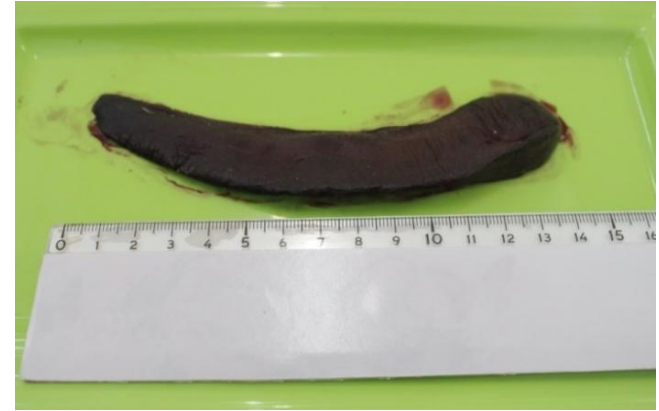

Gambar 2. Limpa hewan coba 18 jam postmortem

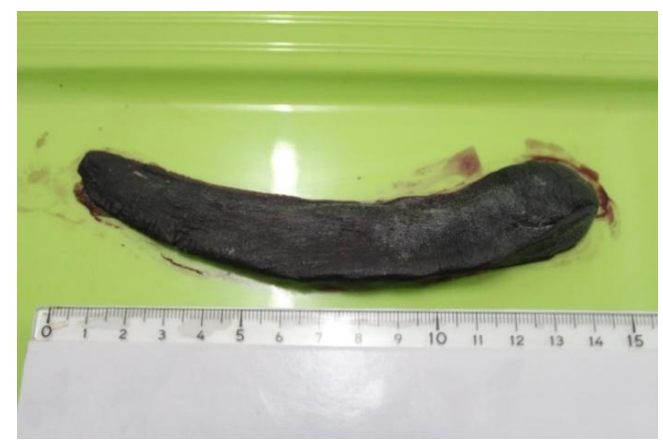

Gambar 3. Limpa hewan coba 30 jam postmortem

inti piknotik. Pada 48 jam postmortem, struktur korpus Malpighi telah sulit diidentifikasi sel-sel korpus mengalami karioreksis dan kariolisis, serta struktur/lapisan dinding arteri sentralis tidak jelas. Trabekula dan arteri Hulsen masih dapat diidentifikasi.

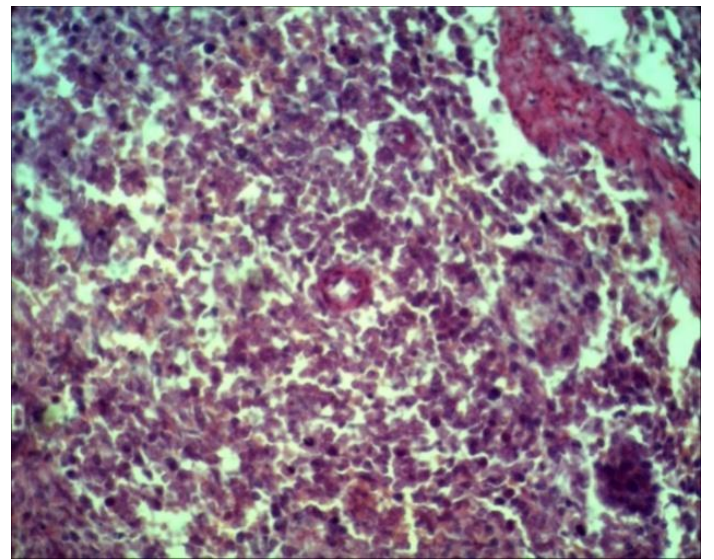

Gambar 5. Limpa hewan coba 5 jam postmortem. Korpus Malpighi mulai mengalami kongesti dengan batas tidak jelas. (400x) 


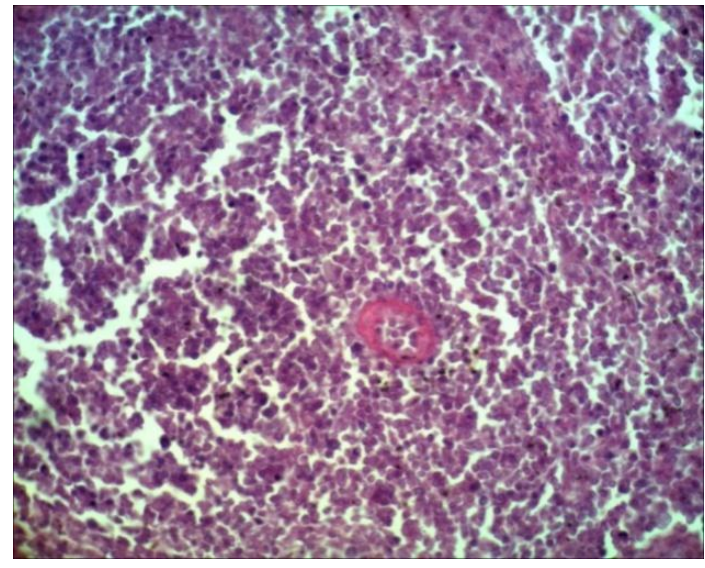

Gambar 6. Limpa hewan coba 24 jam postmortem. Kongesti korpus Malpighi, sebagian besar limfosit dalam korpus Malpihgi dengan inti piknotik (400x).

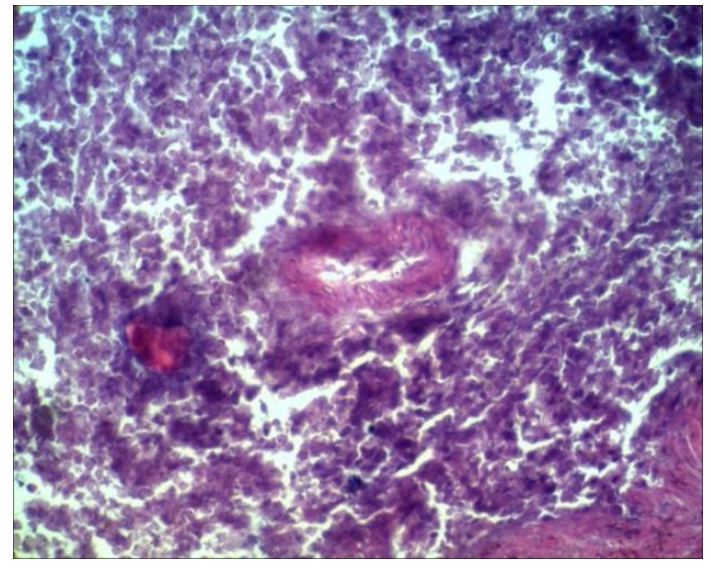

Gambar 7. Limpa hewan coba 48 jam postmortem. Struktur korpus Malpighi sulit diidentifikasi, limfosit korpus dengan karioreksis dan kariolisis, serta struktur lapisan dinding arteri sentralis tidak jelas. Trabekula dan arteri Hulsen masih dapat diidentifikasi. (400x).

proses tersebut menjadi ireversibel dan sel akan mati dan secara morfologik tidak dapat diidentifikasi. Jika sekelompok sel sudah mencapai keadaan ini masih tetap berada dalam host yang hidup selama beberapa jam saja, maka terjadi hal-hal tambahan yang memungkinkan untuk dapat diidentifikasi apakah sel-sel atau jaringan tersebut sudah mati. $^{7}$

Umumnya sel memiliki berbagai jenis enzim. Dalam keadaan hidup, enzim-enzim ini tidak menimbulkan kerusakan sel, tetapi enzim-enzim ini akan dilepaskan pada saat kematian sel dan mulai mencerna berbagai unsur sel. Selain itu, pada saat sel mati terjadi perubahan kimiawi, dan jaringan hidup di sekitarnya berespon terhadap perubahan-perubahan itu antara lain berupa reaksi radang akut dimana terjadi migrasi banyak leukosit yang membantu proses digesti di dalam sel-sel yang mati. Karena enzim-enzim pencernaan tersebut atau sebagai akibat proses radang, maka sel-sel yang sudah mencapai titik puncak tidak dapat kembali lagi dan mulai mengalami perubahan morfologik yang dapat dilihat yaitu berupa tanda-tanda nekrosis (kematian sel ). ${ }^{8}$

Setelah kematian terjadi perubahanperubahan tertentu yang dinamakan perubahan postmortem. Tanda-tanda pasti 
kematian ialah antara lain rigor mortis, algor motris, livor mortis, dan putrefaksi. Enzim-enzim dikeluarkan secara lokal dan mulai terjadi reaksi lisis, yang disebut autolisis postmortem yang sangat mirip dengan perubahan-perubahan yang terlihat pada jaringan nekrotik, tetapi tidak disertai dengan reaksi radang. Bakteri-bakteri akan tumbuh subur dan akan mempercepat terjadinya pembusukan. Kecepatan mulai timbulnya perubahan postmortem berbedabeda tergantung pada individu dan lingkungan sekitarnya. ${ }^{8}$

Pada pengamatan secara makroskopik organ limpa yang normal berwarna merah tua sampai biru kehitaman dengan tepi yang berbentuk lancip atau seperti bulan sabit. Organ limpa yang mengalami kerusakan akan mengalami pembengkakan, berwarna coklat tua atau hampir hitam, dengan tepi yang berbentuk cenderung tumpul atau membulat. ${ }^{9}$ Pada penelitian ini hasil pengamatan secara makroskopik mendapatkan organ limpa yang berwarna merah tua pada 0-1 jam, merah hitam 2-4 jam, coklat hitam 5-9 jam, dan hitam pekat 12-48 jam postmortem. Konsistensi organ limpa kenyal pada 0-1 jam, permukaan mulai kering dan konsistensi kenyal 2-15 jam, bagian tepi mengerut tetapi bagian tengah limpa tetap kenyal 18-24 jam disertai bercak-bercak pucat di bagian tengah organ yang semakin bertambah pada jam-jam terakhir 30-48 jam postmortem. Panjang organ limpa juga diukur dan diperoleh $15 \mathrm{~cm}$ pada 0-4 jam dan perubahan panjang limpa menjadi $14,5 \mathrm{~cm}$ dimulai pada 5 jam postmortem. Berdasarkan hasil pengamatan yang diperoleh terdapat perubahan warna, konsistensi, dan panjang organ limpa antara interval waktu pertama sampai akhir penelitian.

Gambaran mikroskopik limpa normal, yaitu pulpa merah (pulpa rubra) yang terdiri dari sel-sel makrofag, sel plasma, dan elemen darah; dan pulpa putih ( $p u l p a$ alba) yang terdiri dari limfosit tersusun padat di dalamnya dan arteri sentralis pada bagian tengahnya. ${ }^{10}$ Pengamatan secara mikroskopik dilakukan untuk melihat perubahan gambaran histologik organ limpa pada 0-48 jam postmortem. Perubahan dimulai pada 5 jam postmortem ditandai dengan kongesti korpus Malpighi, terdapat celah-celah yang makin melebar di dalam korpus, dan pada 24 jam postmortem terlihat limfosit dalam korpus Malpighi dengan inti piknotik.

Penelitian-penelitian sebelumnya terhadap perubahan struktur mikroskopik berbagai organ dengan hewan coba babi domestik mendapatkan saat terjadi perubahan yang paling awal dan saat struktur organ tidak dapat diidentifikasi yang berbeda-beda untuk organ yang berbeda. Rahmadana et al. ${ }^{3}$ mendapatkan 30 menit postmortem glomeruli (kapsul dan kavum Bowman) serta tubuli proksimal dan distal telah menunjukkan degenerasi hidropik pada sebagian kecil tubuli proksimal yang meluas setelah 45 menit disertai penyempitan kavum Bowman. Nekrosis dari hampir seluruh struktur ditemukan pada 24 jam postmortem. Penelitian oleh Pualillin et al. ${ }^{4}$ melaporkan perubahan gambaran histologik pada hepar dimulai 30 menit postmortem yaitu kongesti parenkim hepar disertai dilatasi sinusoid dan pada 24 jam postmortem lobuli hepar, vena sentralis serta pembuluh-pembuluh dalam area portal tidak dapat diidentifikasi lagi. Penelitian yang dilakukan oleh Lilingan et al. ${ }^{11}$ mengenai gambaran histologik gaster menunjukkan lapisan mukosa dan kelenjar fundus dengan inti sel di bagian basal mulai mengalami perubahan pada 2 jam pertama dan sebagian kecil kelenjar fundus sudah mengalami kongesti. Pada 24 jam postmortem hampir seluruh kelenjar fundus sudah mengalami lisis. Lapian et al. ${ }^{12}$ yang meneliti perubahan mikroskopik pada kolon babi domestik postmortem mendapatkan hasil yang agak berbeda yaitu perubahan mikroskopik paling awal terjadi pada 3 jam postmortem, lisis kripta Lieberkuhn tampak 6 jam postmortem, dan menyeluruh pada 12 jam postmortem. Penelitian oleh Hasan et al. ${ }^{5}$ dengan hewan coba berbeda (sapi Bali) mengenai perubahan autolisis postmortem mendapatkan ginjal mulai mengalami autolisis pada 4 jam postmortem. 
Dengan menbandingkan hasil penelitian-penelitian di atas dapat disimpulkan bahwa setiap organ mempunyai waktu awal terjadinya perubahan mikroskopik dan lisis parenkim organ postmortem yang berbeda-beda walaupun umumnya pada 24 jam postmortem struktur organ telah sulit diidentifikasi. Diharapkan hasil penelitian ini dapat menambah wawasan untuk perkiraan saat kematian.

\section{SIMPULAN}

Berdasarkan hasil penelitian ini dapat disimpulkan bahwa perubahan makroskopik limpa mulai tampak pada 2 jam postmortem limpa yaitu perubahan warna, konsistensi, dan panjang. Perubahan mikroskopik limpa dimulai pada 5 jam postmortem ditandai dengan kongesti korpus Malpighi, 24 jam postmortem limfosit dalam korpus memperlihatkan inti piknotik, dan pada 48 jam postmortem inti limfosit telah mengalami karioreksis dan kariolisis.

\section{SARAN}

Perlu dilakukan penelitian lanjut secara mikroskopik menggunakan pembesaran yang lebih tinggi untuk melakukan pengamatan terhadap perubahan sel yang lebih detil.

\section{UCAPAN TERIMA KASIH}

Ucapan terima kasih ditujukan kepada Dr. dr. Taufiq F. Pasiak, M.Kes, MPdI, dr. Sonny J. R. Kalangi, MBiomed, PA(K), dr. Poppy M. Lintong, $\operatorname{SpPA}(\mathrm{K})$, serta semua pihak baik secara langsung maupun tidak langsung yang telah menumbuhkan ide dan gagasan kepada penulis.

\section{DAFTAR PUSTAKA}

1. Definition of cause of death [cited: 10/10/2016] Available from: http://www.who.int/violence_injury_ prevention/surveillance/databases/mo rtality/en/

2. Ammar M. Lama waktu kematian. Jurnal Media Medika Muda. 2013;2(1)

3. Rahmadana B, Wangko S, Kalangi SJR. Gambaran histologik ginjal hewan coba postmortem. eBm. 2014;2(2): 413-8.

4. Pualillin NK, Wangko S, Kalangi SJR. Gambaran histologik hepar hewan coba postmortem. JBM. 2014;6(2): 98-104.

5. Hasan FA. Perbandingan autolisis organ jantung dan ginjal sapi bali pada beberapa periode waktu pasca penyembelihan. Indonesia Medicus Veterinus. 2015;4(4):305-13.

6. Swindle MM, Makin A, Herron AJ, Clubb FJ Jr, Frazier KS. Swine as models in biomedical research and toxicology testing. Veterinary Pathology. 2012;49(2):344-56.

7. Guyton AC, Hall JE. Buku Ajar Fisiologi Kedokteran (9th ed). Jakarta: EGC, 1997; p. 13-4.

8. Price SA, Wilson LM. Patofisiologi Konsep Klinis Proses-proses Penyakit (4th ed). Jakarta: EGC, 1994; p. 24-8.

9. Nurhaini R, Rahmawati F, Sunyoto. Gambaran histopatologik limpa tikus betina galur Sprague dawley yang diberi ekstrak etanol akar pasak bumi (Eurycoma longifolia Jack) dan diinduksi 7,12-dimetil benz(a) antrazen. Cerata Journal of Pharmacy Science. 2015;2(1):70.

10.Mescher AL. Junqueira's Basic Histology Text and Atlas (13th ed). Singapore: McGraw Hill, 2013.

11.Lilingan M, Kalangi SJR, Wangko S. Gambaran histologik gaster pada hewan coba selama 24 jam postmortem. eBm. 2016;4(1).

12.Lapian C, Wangko S,. Wongkar D. Perubahan histologik pada usus besar hewan coba postmortem. eBm. 2016;4(2). 